\title{
Occupational risks of commercial restaurant workers in the metropolitan region of Recife-PE
}

\section{Riscos ocupacionais de trabalhadores de restaurantes comerciais da região metropolitana de Recife-PE}

\author{
Isabella Carla Ehrhardt Paes ${ }^{1}$ (1), Ruth Cavalcanti Guilherme ${ }^{1}$ (0), Alda Veronica de \\ Souza Livera ${ }^{1}$ (1), Rafael Guilherme Ribeiro do Valle ${ }^{2}$ (1) , Karina Correia da Silveira ${ }^{1 *}$ (1) \\ ${ }^{1}$ Universidade Federal de Pernambuco - UFPE, Centro de Ciências da Saúde - CCS, Departamento de Nutrição, \\ Laboratório de Experimentação e Análise de Alimentos - LEAAL, Recife, PE, Brasil. E-mail: \\ isabelaehrhardt.nutri@gmail.com; karina.silveira@ufpe.br; ruthguilherme@hotmail.com; alda.livera@gmail.com; \\ rafaelguilherme_@hotmail.com \\ 2 Universidade Federal de Pernambuco - UFPE, Centro de Tecnologia e Geociências- CTG, Departamento de \\ Engenharia de Produção, Recife, PE, Brasil. e-mail: rafaelguilherme_@hotmail.com
}

How to cite: Paes, I. C. E., Guilherme, R. C., Livera, A. V. S., \& Valle, R. G. R. Silveira, K. C. (2020).

Occupational risks of commercial restaurant workers in the metropolitan region of Recife-PE. Gestão \& Produção, 27(3), e4330. https://doi.org/10.1590/0104-530X4330-20

\begin{abstract}
With the modern and fast pace of life, the number of people who eat out has increased; consequently there has been an increase in the demand for work in establishments in the collective meals sector, making work environments susceptible to the emergence of occupational risks which may compromise the physical, mental and social health of workers. In order to mitigate these risks, one must have the knowledge of how they can interfere in the quality of life and work of the employees. Considering these aspects, occupational risks were evaluated in two restaurants in the metropolitan area of Recife-PE. For the evaluation of these were studied the levels of noise, heat and illumination. The chemical risks and physical-ergonomic relationship were also evaluated. It was observed in all the analyzes made, some type of discomfort to the collaborators. The noise analysis showed discomfort, where the waiter was exposed to levels of $83 \mathrm{~dB}$, in the heat exposure the cooking area contributed to the thermal discomfort, where the exposure of 30.7 IBTUG was found and insufficient lighting in the area of washing pots with 86 lux. Risks arising from the incorrect use of PPE's and lack of these were found in the handling of chemicals and in the ergonomic risks was observed inadequacy of the height of worktops. From these results, it is fundamental to promote corrective measures to provide a comfortable work environment with reduced wear for the employee, so that there are no negative consequences for the company, as well as the customer.
\end{abstract}

Keywords: Occupational risks; Worker's health; Quality of life.

Resumo: Com o ritmo de vida moderno e acelerado, o número de pessoas que realizam refeições fora casa aumentou, consequentemente houve avanço da demanda de trabalho dos estabelecimentos do setor de refeições coletivas, fazendo com que os ambientes de trabalho se tornem susceptíveis ao surgimento de riscos ocupacionais que podem comprometer a saúde física, mental e social dos trabalhadores. No intuito de amenizar esses riscos, é preciso ter o conhecimento do quanto eles podem interferir na qualidade de vida e de trabalho dos colaboradores. Considerando esses aspectos, foram avaliados os riscos ocupacionais em dois restaurantes da região metropolitana do Recife-PE. Para avaliação desses foram estudados os

Received Nov. 11, 2018 - Accepted May 2, 2019

Financial support: None. 
níveis de ruído, calor e iluminação. Foram também avaliados os riscos químicos e a relação físico-ergonômica. Foi observado em todas as análises feitas, algum tipo de desconforto aos colaboradores. $\mathrm{Na}$ análise de ruído foi verificado desconforto, onde o garçom era exposto a níveis de $83 \mathrm{~dB}$, na exposição ao calor a área de cocção contribuiu para o desconforto térmico, onde foi encontrada a exposição de 30,7 IBTUG e a iluminação insuficiente na área de lavagem de panelas, com 86 lux. Riscos provenientes do uso incorreto de EPI'S e falta destes foram encontrados na manipulação de produtos químicos e nos riscos ergonômicos foi observada inadequação da altura de bancadas para execução do trabalho. A partir desses resultados se torna fundamental a promoção de medidas corretivas para proporcionar um ambiente de trabalho confortável com diminuição do desgaste para o colaborador, de maneira que não haja consequências negativas para o mesmo, para a empresa e também ao cliente.

Palavras-chave: Riscos ocupacionais; Saúde do trabalhador; Qualidade de vida.

\section{Introduction}

The collective meals sector is constantly growing in Brazil, becoming a very significant market in the world economy, an effect of the fast pace of modern life that contributes significantly to this achievement. Changes in the way work is organized, the requirement for production goals, the introduction of new technologies, the acceleration of work rate, the difficulties imposed by long commutes and the long shifts prevent people from having regular meals at home. Therefore, eating away from home have reached quite significant scales and restaurants are becoming one of the main viable alternatives, which leads to the growth of the collective meal sector (Cardoso et al., 2005; Monteiro et al., 2014). Thus for the production of these meals with hygienic-sanitary safety; balanced and tasty in addition to adequate physical resources people remain paramount in the production of meals.

Kitchens activities are characterized by being intense, using forced postures, repetitive movements, excessive and/or improperly weight lifting, that is, an arduous activity. These improper activities and conditions result in dissatisfaction, excessive tiredness, decreased productivity, health problems, increased absenteeism and work accidents (Paula, 2011). The existence of this plurality of problems highlights the importance of studying occupational risks for this sector. Despite all the preparation and infrastructure, workers of a Food and Nutrition Unit (SFNU) are nonetheless risk-free.

Progressively, companies are more concerned with the physical and mental health of their employees, making the organizational structure co-responsible for them. It is noteworthy the need for the appreciation of the human factor by the management of restaurants, and the evolution of this scenario will depend on how much space this work organization will be offering for these workers to exercise their creativity, do experiments and transform the work environment. We can often find workers operating equipment, handling food and other work processes without being aware of the dangers and risks to which they may be exposed, even if these activities may trigger occupational diseases and accidents (Paula, 2011).

In a study conducted with restaurants in São Paulo, between 1988 and 1998, considering Work Accident Reporting (CAT), it was found that $57.5 \%$ of accidents occurred in the kitchen, with the main categories of accidents being burns (45.8\%), followed by musculoskeletal injuries (40.6\%). About the causative object, the CATs showed that 177 of the accidents were due to heat exposure (hot objects and oils), also due to unsafe conditions of slippery floors, improper installations, among other operating risks; and the environment - such as noise, intense heat, poor lighting and high humidity, which can affect workers' health, safety and quality of life (Chamma \& Forastieri, 1999; Barbosa \& Almeida, 2008). According to the National Institute of Social Security, the tertiary sector, which includes the food services sector, has been one of the leaders in 
causes of absence from work in recent years due to illnesses caused by ergonomic risk factors, such as poor health. repetitive postures and efforts (INSS, 2014).

From this context, the concern with the health of workers in commercial restaurants arises, as the awareness that working and health conditions are directly linked to their performance and productivity (Monteiro et al., 2014; Souza \& Silveira, 2011). The health and safety of workers is aimed at promoting their physical, mental and social wellbeing, preventing adverse health outcomes and protecting their work environment. Martins et al. (2016) emphasize the importance of the correct compliance with regulatory standards that ensure the quality of life of employees and consequently the quality of the handled product. In general, work safety aims at the care of the individual for the efficient execution of their tasks.

Creating this awareness in society is perhaps the greatest difficulty in occupational health; recognizing that it is a difficult process to build, that it is necessary to establish dialog spaces in the practical and knowledge field in workers' health from an integrative perspective is a challenge. Given the above, this study aims to identify occupational hazards to which workers of commercial restaurants in the metropolitan region of Recife-PE may be exposed to perform their activities.

\section{Methodology}

This paper is a case study conducted in 2 (two) commercial restaurants in the metropolitan region of Recife-PE. They were identified by the letters "A" and "B" and were chosen randomly. The staff of Restaurant $A$ has 22 employees and capacity to serve 150 people, having as service plated up meals, and, also, self-service buffet only on weekends. Restaurant B has 33 employees and has capacity to serve 250 people, having as a type of service the plated up meals and self-service buffet also on Saturdays and Sundays. Both have a nutrition consulting company.

The noise level was assessed according to Regulatory Standard No. 15 - Unhealthy Activities and Operations of the Brazilian Ministry of Labor. To measure ambient noise levels, a CASSELLA CEL 35X sound level meter was used. To collect this data, the microphone was placed on the shoulder, close to the ear region of an employee from each sector, such as: bar, kitchen, pizzeria, lounge and washing dishes and pans for a period of 100 minutes ( 1 hour and 40 minutes), approximately.

Exposure to heat was assessed according to Regulatory Standard No. 15 of the Brazilian Ministry of Labor and Social Welfare - Unhealthy Activities and Operations (Brasil, 1978). In the heat exposure assessment, the CHROMPACK globe thermometer was used and it was set up and positioned in the place to be measured, remaining a time of approximately 10 minutes for stabilization of the equipment and measurement of the heat emission level. For heat assessment by GTWBI (Globe Thermometer Wet Bulb Index) was considered for metabolism rate, a moderate work when performed standing and when performed on machine or bench, with some movement classified as light work, to base the calculations. The internal GTWBI was also considered: $0.7 \mathrm{nbt}$ (natural wet bulb temperature) $+0.3 \mathrm{gt}$ (globe temperature), recommended for environments without solar charge.

The lighting analysis was performed using a Minipa MLM-1011 luxmeter, it was placed in the workstations of the selected areas, remaining an average time of 10 minutes for equipment stabilization. The illuminance levels were evaluated according to the brazilian rule NBR 5413 (ABNT, 1992).

To assess the chemical hazards, the CSDS (Chemical Safety Data Sheet) of the cleaning products (Chlorine, Neutral Detergent, Disinfectant, Stainless Steel Scourer and Polisher, Dish Soap and Dish Dryer) used by the cleaning aids, general services 
and cookers were analyzed at each restaurant. In the analysis, the availability of PPE was observed, as well as their correct use.

To analyze the ergonomic risk, we performed the measurement of the tables used for assembling dishes, meat cuts, dessert preparation, washing dishes and pans and stove, using Starrett $5 \mathrm{~m}-16$ 'tape measure. It was used as a parameter of adequacy working height between $88 \mathrm{~cm}$ and $100 \mathrm{~cm}$. Average was obtained when considering that, for manual labor standing, the average working height is 95 to $100 \mathrm{~cm}$ for men and 88 to $93 \mathrm{~cm}$ for women (Grandjean, 1998).

All analyzes were accompanied by the occupational safety professional, responsible for the Occupational Health Medical Control Program (OHMCP) and the Environmental Risk Prevention Program (ERPP).

\section{Results and discussions}

According to Lida (2002), noise is physically a mixture of vibrations measured in a logarithmic scale in the $\mathrm{dB}$ unit, the decibel. The human ear is capable of perceiving a scale of sound intensity range from zero to powers equivalent to $130 \mathrm{~dB}$. When this value is exceeded, the pain perception threshold is found, which can damage the hearing system. Table 1 depicts the average noise values in both restaurants studied.

Table 1. Average noise levels by sector in commercial restaurants in the Recife Metropolitan Region (Pernambuco/Brazil).

\begin{tabular}{|c|c|c|c|c|}
\hline Establishment & Position/Function & Schedule & $\begin{array}{c}\text { Noise } \\
\text { level }\end{array}$ & $\begin{array}{l}\text { Continuous/Intermittent } \\
\text { Noise Tolerance Limit }\end{array}$ \\
\hline \multirow{5}{*}{ Restaurant A } & Waiter & 5:45 p.m. to 7 p.m. & $83.0 \mathrm{~dB}$ & \multirow{11}{*}{85 dB $100 \%$} \\
\hline & Barman & 5:45 p.m. to 7 p.m. & $75.1 \mathrm{~dB}$ & \\
\hline & Cooker & 5:30 p.m to $7: 09$ p.m. & $70.3 \mathrm{~dB}$ & \\
\hline & Pizzaiolo & 5:32 p.m to $19: 11$ & $79.3 \mathrm{~dB}$ & \\
\hline & $\begin{array}{c}\text { General Services } \\
\text { Assistant }\end{array}$ & 5:45 p.m. to 7 p.m. & $76.1 \mathrm{~dB}$ & \\
\hline \multirow{6}{*}{ Restaurant B } & Barman & $11: 19$ a.m. to 1 p.m & $66.5 \mathrm{~dB}$ & \\
\hline & Cooker & $\begin{array}{l}\text { 11:37 a.m. to } \\
\text { 12:55 p.m. }\end{array}$ & $75.3 \mathrm{~dB}$ & \\
\hline & Pastrycook & $11: 30$ a.m. to 1 p.m & $73.8 \mathrm{~dB}$ & \\
\hline & Butler & $\begin{array}{l}\text { 11:30 a.m. to } \\
12: 20 \text { p.m. }\end{array}$ & $75.7 \mathrm{~dB}$ & \\
\hline & $\begin{array}{c}\text { General Services } \\
\text { Assistant (pan } \\
\text { washing) }\end{array}$ & $11: 30$ a.m. to 1 p.m. & $78.8 \mathrm{~dB}$ & \\
\hline & $\begin{array}{c}\text { General Services } \\
\text { Assistant (plates } \\
\text { washing) }\end{array}$ & 11:30 a.m. to 1 p.m. & $73.8 \mathrm{~dB}$ & \\
\hline
\end{tabular}

Source: Author (2017).

In the present study, it was observed that the tolerance limit for noise exposure was not exceeded in any of the restaurants surveyed, however, although Albuquerque et al. (2012) analyzed noise levels by areas in a SFNU located in Natal/RN, the values found were higher than those of this research in all environments, except for a time (13:30) of the meat preparation area $(82.9 \mathrm{~dB})$, which may be justified by the decrease in the 
work rhythm. The unit studied by Albuquerque et al. (2012), serves daily 2,800 meals, which could explain these high values.

It is noteworthy that noises between 70 and $80 \mathrm{~dB}$ are already enough to damage health and, above $80 \mathrm{~dB}$, damage the hearing aid, so it is essential to use personal protective equipment (PPE), such as the ear protectors. However, in both restaurants studied, this type of PPE is not available.

In restaurant $A$, the role of a waiter deserves special mention, as he suffers a greater exposure to noise, which reaches the action level close to the allowed limit of $100 \%$ for a workload of 8 hours, considering 100\% the $85 \mathrm{~dB}$ level. Another feature of this professional is the routine of circulating in various areas of the restaurant, which in cases of musical events prevents exposure to high noise levels to be continuous.

In a study conducted in 2014, Monteiro et al. points out that exposure to high noise levels can cause injuries and, in extreme cases, psychosomatic disorders, which may result in hearing loss. This ill is directly related to the health of employees, besides reducing motor coordination, insomnia, mood, balance, cardiovascular disorders, irritability, distraction, nausea, fatigue and reduced concentration. Some of these symptoms such as mood disturbances, irritability and insomnia were mainly reported in the role of cook and waiter at restaurant $A$.

In restaurant B, we highlight the role of General Service Assistant, responsible for washing the pans, as the highest noise level and Bartender as the lowest noise level.

In restaurant $B$, noise exposure levels were within the permitted range for the workday, and the highest level of noise exposure was found for the General Service Assistant function $(78.8 \mathrm{~dB})$ which corresponds to the increase of shock between the metal utensils. Albuquerque et al. (2012) found levels of $99 \mathrm{~dB}$ in this same area and at the same time, probably due to the flow of meals that increases the number of utensils that need cleaning after use.

The Bartender function had the lowest noise exposure level in Restaurant $B$, $66.5 \mathrm{~dB}$, possibly from a lower beverage output at the time.

Average heat values are often related to environmental discomfort. Table 2 shows the average heat values in the two commercial restaurants.

Table 2. Average heat levels by sector in commercial restaurants in the Recife Metropolitan Region (Pernambuco/ Brazil).

\begin{tabular}{|c|c|c|c|c|}
\hline Establishment & Position/Function & Schedule & $\begin{array}{c}\text { Average } \\
\text { heat level }\end{array}$ & $\begin{array}{c}\text { Recommendation } \\
\text { (GTWBI/lenght of } \\
\text { stay) }\end{array}$ \\
\hline \multirow{8}{*}{ Restaurant A } & Steak house & $\begin{array}{l}\text { 6:11 p.m. to } \\
\text { 6:20 p.m }\end{array}$ & 30.2 & \multirow{8}{*}{$\begin{array}{c}30.5 \text { GTWBI/45 } \\
\text { minutes working } \\
\text { and } 15 \text { minutes } \\
\text { resting* }\end{array}$} \\
\hline & Assembling Dishes & $\begin{array}{l}6 \text { p.m. to } 6: 10 \\
\text { p.m }\end{array}$ & 30.2 & \\
\hline & Cooking & $\begin{array}{l}6 \text { p.m. to } 6: 10 \\
\text { p.m }\end{array}$ & 30.2 & \\
\hline & Pan washing & $\begin{array}{l}\text { 6:30 p.m. to } \\
\text { 6:40 p.m. }\end{array}$ & 28.2 & \\
\hline & Plate washing & $\begin{array}{l}\text { 6:20 p.m. to } \\
\text { 6:30 p.m. }\end{array}$ & 28.5 & \\
\hline & \multicolumn{3}{|c|}{ Pizzeria } & \\
\hline & Preparation & $\begin{array}{l}\text { 6:50 p.m. to } 7 \\
\text { p.m. }\end{array}$ & 26.1 & \\
\hline & Cooking & $\begin{array}{l}\text { 6:50 p.m. to } 7 \\
\text { p.m. }\end{array}$ & 26.1 & \\
\hline
\end{tabular}


Table 2. Continued...

\begin{tabular}{|c|c|c|c|c|}
\hline Establishment & Position/Function & Schedule & $\begin{array}{c}\text { Average } \\
\text { heat level }\end{array}$ & $\begin{array}{c}\text { Recommendation } \\
\text { (GTWBI/lenght of } \\
\text { stay) }\end{array}$ \\
\hline \multirow{6}{*}{ Restaurant B } & Steak house & $\begin{array}{l}\text { 12:10 p.m. to } \\
\text { 12:18 p.m. }\end{array}$ & 30.3 & \\
\hline & Assembling Dishes & $\begin{array}{l}\text { 11:58 a.m. to } \\
\text { 12:18 p.m. }\end{array}$ & 30.7 & \\
\hline & Cooking & $\begin{array}{l}\text { 11:58 a.m. to } \\
\text { 12:10 p.m. }\end{array}$ & 30.7 & \\
\hline & Pan washing & $\begin{array}{l}\text { 12:18 p.m. to } \\
\text { 12:24 p.m. }\end{array}$ & 31.1 & \\
\hline & Plate washing & $\begin{array}{l}\text { 12:10 p.m. to } \\
\text { 12:18 p.m. }\end{array}$ & 30.0 & \\
\hline & Cooking (Pastry) & $\begin{array}{l}12: 29 \text { p.m. to } \\
12: 35 \text { p.m. }\end{array}$ & 29.0 & \\
\hline
\end{tabular}

*For moderate activity. Source: Author (2017).

As for the GTWBI heat values, we can observe from Table 2 that restaurant $B$ values are slightly higher than restaurant $A$ for the same areas. $A$ factor that may have contributed to this situation would be the day period the analyzes were performed. In restaurant $B$, the analyzes took place around 12 a.m., in this period the incidence of sun rays is higher than 6 p.m, when it took place in restaurant $A$.

In restaurant $A$, of the evaluated sectors, the cooking areas were responsible for the highest values (Steakhouse and Cooking) and the assembling dishes area, due to its proximity to the cooking area, but the tolerance limit for occupational heat exposure not have been exceeded. The food cooking sector is usually the place that generates the biggest discomfort for employees. Albuquerque et al. (2012) identified high heat levels in the cooking area, with equipment such as stove, fryer, grills and ovens responsible for raising the temperature of the environment.

In restaurant $\mathrm{B}$, in the assembling dishes and cooking areas, the average heat level exceeded the recommended for activity, reaching an average heat level of $30.7 \mathrm{GTWBI}$. The pan washing area deserves attention since it presented an average heat level of 31.1 GTWBI. This fact can be explained by the proximity of the cooking area and the period that measurement was made, during an intense activity time, unlike restaurant $A$, where an average heat level of 28.2 GTWBI was found in the same area, but in a non-intense activity time, which also explains what was found in restaurant $A$ pizzeria.

According to Teixeira et al. (2010), the ideal temperature for food service operations is between $22^{\circ} \mathrm{C}$ and $26^{\circ} \mathrm{C}$ with relative humidity between 50 and $60 \%$. When elevated, temperature levels directly influence human work performance, both productivity and accident risks. In kitchens, unfavorable conditions can contribute to a thermal imbalance, as they contribute to increase body temperature, in which case it is essential to use appropriate clothes and shoes that allow greater comfort (Lida, 2002). In both restaurants $(A$ and $B)$ the uniforms are adequate.

Another aspect to be considered is the state of conservation and proper dimensioning of the exhausters, because, when inadequate, it is insufficient and the fat accumulations of the ducts cause the loss of air flow power, preventing the heat emitted by the equipment to be slowed down. In both restaurants ( $A$ and $B$ ) the maintenance of the exhaust system is regular.

As for lighting, Vieira \& Japur (2012) state that the ideal of a kitchen is a natural one, but to achieve the recommended level of lighting in a way that is uniform, without 
glare, shadows and dark corners, natural lighting needs to be complemented by artificial lighting. With proper lighting, the risks of eye strain, fatigue, number reading errors, recipe measurements, dish and pan residue are all reduced.

In restaurant $A$, the lighting uses natural and artificial light. When evaluating the results, it was found that the lighting values are always lower at the time around 5 p.m. than at the hours around 12 a.m., highlighting the need for improvement in artificial light. Thus, cleaning existing lamps and using LED lamps, that are economical, does not emit heat and are more sustainable, become viable alternatives.

Illuminance indices were lower than recommended by the brazilian rule NBR 5413 (ABNT, 1992), Abreu et al. (2011) and Sant'Ana (2012): respectively, 200 Lux, 250 Lux and 400 Lux in the pan washing areas and pastry. Meat pre-preparation area presented the lowest values (101 to 114 Lux), which could lead to the emergence of visual diseases, decreased work efficiency leading to greater waste of material and increased number of accidents.

The pizzeria area also had an illuminance index (154, 193 and 146 Lux) which is lower than recommended by the brazilian rule NBR 5413 (ABNT, 1992). However, it is an area located in the saloon inside of restaurante $A$, which has a most romantic proposal. In order to not lose this theme, lighting improvement is suggested in the worker's place of labor.

In other sectors of restaurant $A$, illuminance levels were within the requirements of the brazilian rule NBR 5413 (ABNT, 1992), as shown in Table 3, undergoing some oscillations throughout the day, due to the inefficiency of artificial lighting to complement the decrease in natural light in these areas, as perceived by employees.

The illuminance values of the areas of the two restaurants can be seen in Table 3 . In restaurant $B$, lighting is completely artificial and no area fulfills the brazilian rule NBR 5413 (ABNT, 1992). Highlighting the pan washing area, that presented the lowest illuminance indexes (86, 92 and 98 Lux), this area showed a deficiency of lamps, working only with one lamp in the luminaire, a fact that may be harmful in the long run to their vision, even without the knowledge of the employees. A different result was found by Albuquerque et al. (2012), who found in their study illuminance index of 188 lux in the same area, and Monteiro in 2014, when studying commercial restaurants in Belo Horizonte that found higher illumination values in three of the four restaurants studied for the dining areas.

Table 3. Lighting levels by sector in commercial restaurants in the Recife Metropolitan Region (Pernambuco/Brazil).

\begin{tabular}{|c|c|c|c|}
\hline Stablishment & Benchmarked area & Schedule & Lux \\
\hline \multirow{12}{*}{ Restaurant A } & \multirow{3}{*}{ Meat pre-preparation } & $11: 30$ a.m. & 114 \\
\hline & & 02:00 p.m. & 111 \\
\hline & & 05:00 p.m. & 101 \\
\hline & \multirow{3}{*}{ Assembling dishes } & 11:40 a.m. & 294 \\
\hline & & 02:15 p.m. & 205 \\
\hline & & 05:10 p.m. & 102 \\
\hline & \multirow{3}{*}{ Plate washing } & 12:00 p.m. & 457 \\
\hline & & 02:40 p.m. & 338 \\
\hline & & 05:25 p.m. & 285 \\
\hline & \multirow{3}{*}{ Pan washing } & 12:55 p.m. & 189 \\
\hline & & 02:50 p.m. & 178 \\
\hline & & 05:35 p.m. & 131 \\
\hline
\end{tabular}


Table 3. Continued...

\begin{tabular}{|c|c|c|c|}
\hline Stablishment & Benchmarked area & Schedule & Lux \\
\hline & & 11:50 a.m. & 154 \\
\hline & Pastry & 02:23 p.m. & 167 \\
\hline & & 05:15 p.m. & 144 \\
\hline & & 11:50 a.m. & 154 \\
\hline & Pizzeria & 03:00 p.m. & 193 \\
\hline & & 05:45 p.m. & 146 \\
\hline \multirow{18}{*}{ Restaurant B } & \multirow{3}{*}{ Meat pre-preparation } & 10:00 a.m. & 135 \\
\hline & & 11:00 a.m. & 135 \\
\hline & & 12:00 p.m. & 132 \\
\hline & \multirow{3}{*}{ Assembling dishes } & 10:05 a.m. & 173 \\
\hline & & 11:05 a.m. & 154 \\
\hline & & 12:05 p.m. & 158 \\
\hline & \multirow{3}{*}{ Pan washing } & 10:15 a.m. & 86 \\
\hline & & 11:15 a.m. & 92 \\
\hline & & 12:15 p.m. & 98 \\
\hline & \multirow{3}{*}{ Plate washing } & 10:20 a.m. & 115 \\
\hline & & 11:20 a.m. & 102 \\
\hline & & 12:20 p.m. & 121 \\
\hline & \multirow{3}{*}{ Pastry } & 10:30 a.m. & 102 \\
\hline & & 11:30 a.m. & 92 \\
\hline & & 12:30 p.m. & 95 \\
\hline & \multirow{3}{*}{ Pizzeria } & 10:40 a.m. & 165 \\
\hline & & 11:40 a.m. & 160 \\
\hline & & 12:40 p.m. & 164 \\
\hline
\end{tabular}

Source: Author (2017).

The light intensity is directly related to restaurant infrastructure in terms of sunlight incidence and use of artificial light. In the studied restaurants ( $A$ and $B$ ), the one that uses natural and artificial lighting $(A)$, in general, obtained better results than the restaurant that uses only artificial lighting $(B)$.

When designing workplaces, it is important to have the correct choice of the height of the tables and countertops, which when too high, make the shoulders lift to compensate, leading the individual to have muscle contractions in the neck and back; when too low, the back is hampered by the overload of excess trunk curvature, giving pain (Grandjean, 1998).

According to Vieira \& Japur (2012), ergonomic risks from ill-defined spaces and dimensions cause divergences between proper posture, workers' movements and their jobs, which may cause fatigue, discomfort and injury. The ergonomics in the occupational areas, or even of the worker in the performance of activities, when inadequate, can lead to the emergence of Work-Related Musculoskeletal Disorders (WMSD) and Repetitive Strain Injury (RSI).

Actions such as resizing the physical space, the implementation of a labor gymnastics program and the alternation of activities, avoiding repetitive work for a long period, can minimize discomfort and work-related complaints (Vieira \& Japur, 2012). In this way, it would be ideal for the height of the countertops to be adjusted to allow workers greater comfort. Thus the values obtained in this study are shown in Table 4. 
Table 4. Physical-structural relationship of commercial restaurants in the Recife Metropolitan Region (Pernambuco/Brazil) in ergonomics.

\begin{tabular}{ccc}
\hline Equipament & Restaurant A & Restaurant B \\
\hline Stove & $85.0 \mathrm{~cm}$ & $85.0 \mathrm{~cm}$ \\
\hline Desserts and salads pre-preparation & $91.5 \mathrm{~cm}$ & $88.0 \mathrm{~cm}$ \\
\hline Meat pre-preparation & $87.0 \mathrm{~cm}$ & $86.0 \mathrm{~cm}$ \\
\hline Assembling dishes & $88.0 \mathrm{~cm}$ & $84.0 \mathrm{~cm}$ \\
\hline Pan washing & $89.0 \mathrm{~cm}$ & $86.0 \mathrm{~cm}$ \\
\hline Plate washing & $87.0 \mathrm{~cm}$ & $84.0 \mathrm{~cm}$ \\
\hline
\end{tabular}

Source: Author (2017).

In restaurant A, the height of the countertops, when compared to Grandjean (1998), shows that, in the areas of the stove, meat pre-preparation and dish washing, the countertops are not suitable for work. The preparation of desserts and salads, the setting up of dishes and the washing of pans countertops are adequate. In restaurant A there are common complaints of back pain, reported by cleaning assistants, because they use the dishwasher countertop.

In restaurant $\mathrm{B}$, only the dessert and salad pre-preparation countertops proved to be with appropriate height for the work activities. It is important to highlight that all prepreparation and preparation areas of restaurant $B$ have male workers for its production and operation, and from the measurements obtained and compared with that proposed by Grandjean (1998), it was found that none of the countertops of restaurant B had the recommended height for the work performed by these workers.

It is important to highlight that, during the research period, all activities performed on the countertops of the two restaurants are performed standing, analogous to that verified by Albuquerque et al. (2012), in which only one of the countertops in the cooking area was suitable for standing work performance and others inappropriate.

When considering the sitting working position, Grandjean (1998) suggests that the bench height varies between 71 and $76 \mathrm{~cm}$. Looking at Table 4, we also found that restaurants $A$ and $B$ do not have adequate countertops to perform activities in the sitting position. It was observed that the area workers, while performing their duties, remained with their hands and elbows above shoulder level when preparing food. The neck was bent forward, especially while cutting vegetables and meat and making desserts and snacks.

Thus, with regard to ergonomics, it was observed that in both restaurants, there are countertops that are not at the right height for work, making adjustments necessary to better perform the tasks.

Regarding chemical risks, when analyzing the MSDS and the execution of activities, it was found that the lack of care in the handling of the chemicals used can be the main causes of accidents and injuries to workers.

In the two restaurants studied, it was observed that the use of PPE is not done correctly, especially in the handling of descaler. In the recommendations of the descaler manufacturers, the product should be handled using safety goggles, face shield, gloves and PVC boots. However, in the direct observational analysis, it was found that, in both restaurants, not all PPE are available and, among those that are, workers do not use them. In the handling of the descaler the procedure glove is used; safety goggles and face shield (OVIAG mask - organic vapor/acid gas) are available for use, but are not worn due to lack of sensitivity and disrupting the handling of sponge and other cleaning aids of equipment, according to the workers.. 
Employees who perform the function of general service assistant use all products for environmental hygiene, equipment and utensils. In observing the use of the products, it was found that the rubber glove is used, but not the one with long barrel, as recommended. Teixeira et al. (2015) evidenced the prevalence of 25 to $45 \%$ of lack of training for the use of cleaning products, as well as the absence of appropriate PPE to perform the activities. It was also identified that the collaborators had peeling lesions on the skin of the hands, which reinforces the hypothesis of damage caused by the chemical without the use of PPE.

In the two restaurants studied, were identified, in general service assistants, injuries caused by inappropriate use of PPE. In restaurant $A$, one worker had scaly lesions on his hands, and, in restaurant $B$, one worker had a minor burn on his forearm from splatter on the site.

Chemicals, when absorbed by the body in high amount and time of exposure, can cause a number of injuries in the body, including: burns, encephalopathies and skin ulcerations. Since these chemical agents can penetrate the body through the respiratory, digestive, dermal and ocular pathways, we can state that the main preventive measures to be taken include the training and use of PPE (Sousa et al., 2005).

Highlighting the importance of PPE, Conceição \& Cavalcanti (2001) demonstrated that $94 \%$ of workers recognize the importance of equipment. However, $50 \%$ suggested that they feel discomfort or difficulty in using PPE, which may be associated with misuse, lack of custom or inadequate equipment. These values are similar to those found by Hagen et al. (2012), where $82.5 \%$ of workers acknowledged the importance of using PPE and $50 \%$ said they felt discomfort and/or difficulty in use.

When it comes to chemical hazards, it was found that there is no availability of all PPE necessary to protect the handling of products, and of those available, the employees of both restaurants do not make the correct use, which demonstrates the need for training as a corrective measure.

\section{Conclusion}

By observing the aspects analyzed, it can be concluded that both restaurants are exposing their employees to occupational risks that may cause health problems in short, medium and long term. The risks found and highlighted involve physical aspects of noise, heat, lighting, chemicals and ergonomics.

The out-of-home dining market offers thousands of direct jobs, requiring workers to be highly productive in limited time, with working conditions that often contribute to health problems, work-related injuries and overtime dissatisfaction. Food services, in search of meal acceptance and customer satisfaction, and in addition to the concern with the menu, need to understand that the workforce remains a prime factor for meal quality.

Corrective measures should be provided to make an adequate working environment to perform the activities, comfortable and with reduced detrition for the employee, so that there are no negative consequences for the employee, the company and the customer. Thus, it is hoped that this study can bring contributions and enable new reflections and methodological improvement in intervention spaces and attention to worker health in food services. 


\section{References}

Abreu, E. S., Spinelli, M. G., \& Pinto, A. M. S. (2011). Gestão de unidades de alimentação e nutrição: um modo de fazer (2. ed.). São Paulo: Metha.

Albuquerque, E. N., Seabra, L. M. J., Rolim, P. M., \& Gomes, L. M. (2012). Riscos físicos em uma unidade de alimentação e nutrição: implicações na saúde do trabalhador. Revista da Associação Brasileira de Nutrição, 4(1), 40-47.

Associação Brasileira de Normas Técnicas - ABNT. (1992). NBR 5413: iluminância de interiores. Rio de Janeiro: ABNT.

Barbosa, L.N. \& Almeida, F.Q.A. (2008). Relato de experiência sobre a avaliação dos riscos ambientais e mapeamento em uma Unidade de Alimentação e Nutrição (UAN) para a promoção da segurança no trabalho. Botucatu: Unesp.

Brasil. Ministério do Trabalho e da Previdência Social. (1978). Normas regulamentadoras de segurança e saúde no trabalho: NR 15: atividades e operações insalubres. Brasília.

Cardoso, R. C. V., Souza, E. V. A., \& Santos, P. Q. (2005). Unidades de alimentação e nutrição nos campus da Universidade Federal da Bahia: um estudo sob a perspectiva do alimento seguro. Revista de Nutrição, 18(5), 669-680. http://dx.doi.org/10.1590/S141552732005000500010.

Chamma, L., \& Forastieri, N. (1999). Análise ergonômica de acidentes de trabalho e doenças ocupacionais em restaurantes, ao longo de dez anos. In Anais do XV Congresso Mundial sobre Segurança no Trabalho. São Paulo.

Conceição, M. L., \& Cavalcanti, C. L. (2001). Avaliação dos Equipamentos de Proteção Individual (EPIs) na Unidade de Alimentação e Nutrição (UAN) do Restaurante Universitário da UFPB. Revista Conceitos, 4(5), 105-108.

Grandjean, E. (1998). Manual de ergonomia adaptando o trabalho ao homem. Porto Alegre: Bookman.

Hagen, M. E. K., Soltys, A. A., Valmórbida, J. L., Louzada, M. L. C., \& Zani, V. T. (2012). O uso de equipamentos de proteção individual pelos funcionários de unidade de alimentação e nutrição de um hospital público do sul do Brasil. Nutrição Brasil, 11(3), 167-171.

Instituto Nacional do Seguro Social - INSS. (2014). Saúde e segurança do trabalho: estudo da previdência social indica mudança nas causas de afastamento do trabalho. Brasília. Retrieved in 2012, December 12, from http://www.previdencia.gov.br/2014/04/saude-eseguranca-do-trabalho-estudo-da-previdencia-social-indica-mudanca-nas-causas-deafastamento-do-trabalho/

Lida, I. (2002). Ergonomia: projeto e produção. São Paulo: Edgard Blücher.

Martins, E. N., Herculano, I. R., \& Santos, M. C. T. (2016). A importância da saúde, ergonomia e segurança em um ambiente de produção de alimentação coletiva ou comercial. Revista Conexão Eletrônica, 13(1), 1-9.

Monteiro, M. A. M., Ramos, C. G. C., Ribeiro, C. R., \& Garcia, M. A. V. T. (2014). Condições de trabalho em restaurantes comerciais de uma instituição pública de ensino. O Mundo da Saude, 38(3), 306-313. http://dx.doi.org/10.15343/0104-7809.20143803306313.

Paula, C. M. D. (2011). Riscos ocupacionais e condições de trabalho em cozinhas industriais (Especialização). Universidade Federal do Rio Grande do Sul, Porto Alegre.

Sant'Ana, H. M. P. (2012). Planejamento físico funcional de unidades de alimentação e nutrição (1. ed.). Rio de Janeiro: Rubio.

Sousa, J., Silva, C., Pacheco, E., Moura, M., \& Fabela, S. (2005). Acidentes de trabalho e doenças profissionais em Portugal: regime jurídico da reparação dos danos. Portugal: CRPG. Retrieved in 2014, August 13, from: http://www.crpg.pt/estudos/Projectos/Documents/factoresriscoergonomico.pdf 
Souza, R. C., \& Silveira, F. S. A. (2011). Análise ergonômica do trabalho (AET) em uma unidade produtora de refeição na cidade de Viçosa, MG. Anais SIMPAC, 3(1), 32-38.

Teixeira, S. A., Luz, N. S., Oliveira, E. S., Almondes, R. S. M., Moraes, C. A., Lucena, J. D., \& Barros, H. B. (2015). Investigação dos riscos ambientais e ergonômicos em restaurantes privados de um município do Piauí, Brasil. Revista Intertox-EcoAdvisor de Toxicologia Risco Ambiental e Sociedade, 8(1), 113-130. http://dx.doi.org/10.22280/revintervol8ed1.197.

Teixeira, S. M. F. G., Oliveira, Z. N. C., Rego, J. C., \& Biscontini, T. M. B. (2010). Administração aplicada as unidades de alimentação e nutrição. São Paulo: Atheneu.

Vieira, M. C. N. M., \& Japur, C. C. (2012). Gestão de qualidade na produção de refeições (1. ed.). Rio de Janeiro: Guanabara. 